\title{
DETERMINATION OF THE COMBUSTION CHARACTERISTICS OF CHIKILA COAL THROUGH THE KISSINGER KINETICS MODEL
}

\author{
Bemgba Bevan Nyakuma ${ }^{1, 凶}$
}

https://doi.org/10.23939/chcht14.03.433

\begin{abstract}
The combustion characteristics of Chikila coal (CHK) from Nigeria have been examined. It was established that CHK has a high carbon and fixed carbon content, but low nitrogen, sulphur, and ash content. Based on coal heating value, it was classified as a high volatile $B$ bituminous coal. The temperature profile characteristics were examined through thermogravimetric analysis. The combustion kinetics of CHK was examined based on the Kissinger model. It is shown that CHK is a potentially good feedstock for future energy recovery and industrial utilization.
\end{abstract}

Keywords: combustion, thermal kinetics, Chikila coal.

\section{Introduction}

Combustion is an integral process in the energy recovery and electricity production from coal. According to the IEA, pulverised coal combustion accounts for $40 \%$ of electricity production and one-third of all energy consumed around the globe [1]. Coal is also an important raw material for the cement, iron and steel industries [2]. As a result, energy analysts predict that the demand, supply, and utilization of coal will continue to rise for the foreseeable future [3]. These projections come against the backdrop of growing concerns about greenhouse gas (GHG) emissions, global warming, and climate change [4]. However, the growing demand for energy around the globe is expected to expand coal utilization for electricity, particularly in countries such as Nigeria, with its perennial energy crises despite large deposits [5].

In spite of Nigeria's position as Africa largest economy, the nation is plagued by a perpetual energy crisis $[6,7]$. This has hampered socio-economic growth and sustainable development despite the nation's vast human, mineral, and energy sources like petroleum and coal [8]. According to analysts, Nigeria's energy crises is attributed to poor generation, transmission, distribution

\footnotetext{
${ }^{1}$ Hydrogen \& Fuel Cell Laboratory, School of Chemical \& Energy Engineering,

Universiti Teknologi Malaysia, 81310 Skudai, Johor Bahru, Malaysia

\bbnyax1@gmail.com

(c) Nyakuma BB., 2020
}

and marketing [8], which results in persistent power cuts and extended blackouts yearly [9]. However, electricity production from Nigeria's coal resources has been identified as a potential solution to the nation's energy crises [10]. Currently, Nigeria's proven reserves of coal stand at 640 million tonnes comprising $12 \%$ lignite, $49 \%$ sub-bituminous, and $39 \%$ bituminous [11]. Nonetheless, coal utilization for electricity production and industrial utilization remains low in Nigeria [12]. This is attributed to numerous socioeconomic, geopolitical, environmental and technological factors. The most notable drawback is the lack of comprehensive technical data such as the fuel properties of Nigerian coals [13]. Some studies have examined the geological [14-16], rheological [17, 18], petrographic $[19,20]$ properties on various ranks of Nigerian coals. However, the requisite technological data on the physicochemical, thermal, kinetic and thermodynamic properties of Nigerian coals are still lacking.

Therefore, this paper aims to examine and highlight the physico-chemical, temperature profiles, and calorific fuel properties of Chikila coal (CHK) from the upper Benue trough in Nigeria. It also presents the comprehensive data on the combustion characteristics, thermal behaviour, and degradation kinetics of CHK. Previous studies have examined the thermal analysis [21], pyrolysis and tar evaluation [22], mineralogical analysis [23] and organic geochemistry [14] of CHK in literature. To the best of authors' knowledge, there are limited data on the physico-chemical and thermokinetic fuel properties of Chikila coal, which this paper will address in detail.

\section{Experimental}

\subsection{Sample Preparation}

The Chikila coal sample (CHK) was acquired from the National Metallurgical Research and Development Centre (NMRDC), Jos in the Plateau State, Nigeria. The samples were initially obtained in a rock form from a coal deposit in the village of Chikila located on the outskirts of Guyuk town, Nigeria [22]. Therefore, it is located within the upper Benue Trough of Nigeria's sedimentary basin. 
Next, the sample was pulverised in a dry miller (Panasonic mixer grinder model: MX-AC400, Malaysia) before sieving with an analytical sieve (mesh size 60 from Retsch $^{\mathrm{TM}}$, Germany) to obtain $250 \mu \mathrm{m}$ sized particles. Next, the pulverised sample was characterised by physicochemical, thermal, and kinetic analyses.

\subsection{Physico-chemical Fuel Characteristics}

The physico-chemical properties of CHK were examined by ultimate, proximate, and higher heating value analysis. The ultimate analysis was conducted according to the ASTM standard D5373-93, using the elemental CHNS analyser (Vario MACRO Cube, Germany). Proximate analysis was performed by a thermogravimetric analysis (TGA model: Shimadzu TG-50, Japan) to determine the moisture content (MC), volatile matter (VM), and ash content (AC) according to the procedure described in the literature [24]. However, the fixed carbon (FC) was determined by difference. The higher heating value (HHV) was determined based on the isoperibolic procedure of the bomb calorimeter (IKA C2000, USA) according to the ASTM standard D2015. Each test was performed in duplicate to establish the reliability and accuracy of the results presented as average values in this study.

\subsection{Oxidative Thermal Analysis}

The oxidative thermal analysis of CHK was performed using a non-isothermal heating program. For each test, about $16 \mathrm{mg}$ of sample was placed in an alumina crucible before transferring to the sample holder of the thermogravimetric analyser (TGA model: Shimadzu TG-50, Japan). Next, the crucible and the sample were heated from 298 to $1173 \mathrm{~K}$ at variable heating rates of 10,20 , and $30 \mathrm{~K} / \mathrm{min}$ using air (flow rate $20 \mathrm{ml} / \mathrm{min}$ ) to purge the evolved gases and simulate oxidative (combustion) thermal analysis. On completion, the raw TG data were retrieved and processed using the Shimadzu TA-60WS Workstation to deduce the mass loss (TG, \%) and derivative mass loss (DTG, \%/min). Next, the TG and DTG data were plotted against temperature $(\mathrm{K})$ as presented in Figs. 1 and 2.

\subsection{Temperature Profile Characteristics}

The temperature profile characteristics (TPC) of CHK were deduced from the TG and DTG plots. The TPCs deduced from the TG plots in this study were: ignition $\left(T_{o n}\right)$, midpoint $\left(T_{m i d}\right)$, and burnout $\left(T_{o f f}\right)$ temperatures, mass loss $\left(M_{L}, \%\right)$ and residual mass $\left(R_{M}\right.$, $\%)$. However, the TPCs deduced from the DTG plots were: drying peak temperature $(\mathrm{K})$ and devolatilization peak temperature $\left(T_{\max }, \mathrm{K}\right)$. Based on the TPCs, the effects of temperature and multi-heating rates were examined during the oxidative thermal analysis of CHK from 298 to $1173 \mathrm{~K}$ at 10,20 , and $30 \mathrm{~K} / \mathrm{min}$, respectively.

\subsection{Combustion Kinetic Analysis}

The combustion kinetics of CHK was examined based on the Kissinger model. This is a model-free method used to calculate the kinetic parameters, activation energy $\left(E_{a}\right)$ and frequency factor $(A)$, from the plot of $\ln \left(\beta / T^{2}{ }_{m}\right)$ against $1000 / T_{m}$ for a thermally decomposing material at different heating rates $\beta$. The term $T_{m}$ represents the maximum or peak decomposition temperature on the DTG curve. The Kissinger model is given as [25]:

$$
\ln \left(\frac{\beta}{T_{m}^{2}}\right)=\ln \left(\frac{A R}{E_{a}}\right)-\left(\frac{E_{a}}{R T_{m}}\right)
$$

Based on the equation, the activation energy $E_{a}$ and frequency factor $A$ can be determined from the slope and the intercept of the plots, respectively.

\section{Results and Discussion}

\subsection{Physico-chemical Fuel Characteristics}

Table 1 presents the physico-chemical properties of CHK in terms of its ultimate and proximate analysis, as well as higher heating value (HHV).

The results indicate that $\mathrm{CHK}$ has high $\mathrm{C}, \mathrm{H}$, and $\mathrm{O}$ but low $\mathrm{N}$ and $\mathrm{S}$ content. Furthermore, $\mathrm{C}, \mathrm{H}$, and $\mathrm{O}$ contents are within the range of 62.9-86.9, 3.5-6.3 and $4.4-29.9 \mathrm{wt} \%$, respectively, as typically reported for coals in the literature [26]. The proximate properties of CHK revealed high fixed carbon (FC) and volatiles (VM) compared to its low ash (AC) and moisture (MC) content. Similarly, the proximate properties are in good agreement with the range of values reported for coals in the literature.

The calorific value analysis revealed that $\mathrm{CHK}$ has a significantly high $\mathrm{HHV}(30.70 \mathrm{MJ} / \mathrm{kg})$, which is in the upper limits of values $(16.0-34.0 \mathrm{MJ} / \mathrm{kg})$ reported in the literature [26]). The HHV of $\mathrm{CHK}$ can be ascribed to its high $\mathrm{C}$ (73.57 wt \%), and low $\mathrm{O}(18.21 \mathrm{wt} \%), \mathrm{MC}$ and AC, reported in Table 1. In accordance with ASTM standard D388-12 for classification of coals by rank [27], CHK can be categorised as high volatile B bituminous based on its HHV which falls within the range of 30.23$32.56 \mathrm{MJ} / \mathrm{kg}, \quad \mathrm{FC}<69 \%$ and $\mathrm{VM}>31 \%$. However, previous studies have classified CHK as a sub-bituminous (SBT) coal in the literature [28]. The results of this study, however, indicate $\mathrm{CHK}$ as an agglomerating high-rank bituminous coal with potential applications in the manufacture of steel, cement, and electricity generation [2]. 
Determination of the Combustion Characteristics of Chikila Coal Through the Kissinger Kinetics Model 435

Table 1

Physico-chemical and calorific fuel properties of CHK

\begin{tabular}{|c|c|c|c|}
\hline Coal analysis & Fuel properties description & Symbol, units & Values \\
\hline \multirow{4}{*}{ Ultimate analysis } & Carbon & $\mathrm{C}, \mathrm{wt} \%$ & 73.57 \\
\cline { 2 - 4 } & Hydrogen & $\mathrm{H}, \mathrm{wt} \%$ & 5.96 \\
\cline { 2 - 4 } & Nitrogen & $\mathrm{N}, \mathrm{wt} \%$ & 0.58 \\
\cline { 2 - 4 } & Sulphur & $\mathrm{S}, \mathrm{wt} \%$ & 18.21 \\
\cline { 2 - 4 } Elemental correlation & Oxygen & $\mathrm{O}, \mathrm{wt} \%$ & 0.08 \\
& & $\mathrm{H} / \mathrm{C}$ & 0.25 \\
\cline { 2 - 4 } & \multirow{3}{*}{ Atomic ratios } & $\mathrm{O} / \mathrm{C}$ & 0.02 \\
\cline { 2 - 4 } & & $\mathrm{N} / \mathrm{C}$ & 43.80 \\
\hline \multirow{3}{*}{ Heating values } & Higher heating value & $\mathrm{HHV}, \mathrm{MJ} / \mathrm{kg}$ & 30.70 \\
\cline { 2 - 4 } & Moisture content & $\mathrm{MC}, \mathrm{wt} \%$ & 3.11 \\
\cline { 2 - 4 } & Volatile matter & $\mathrm{VM}, \mathrm{wt} \%$ & 54.41 \\
\cline { 2 - 4 } & Ash content & $\mathrm{AC}, \mathrm{wt} \%$ & 7.62 \\
\cline { 2 - 4 } & Fixed carbon & $\mathrm{FC}, \mathrm{wt} \%$ & 34.86 \\
\hline
\end{tabular}

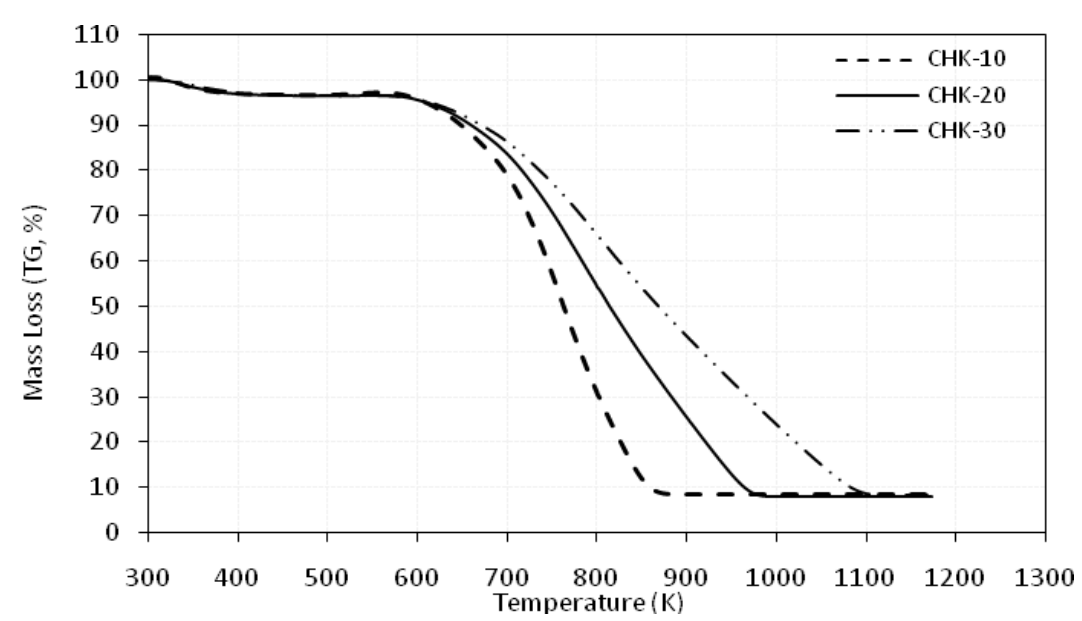

Fig. 1. TG curves for oxidative thermal analysis of CHK

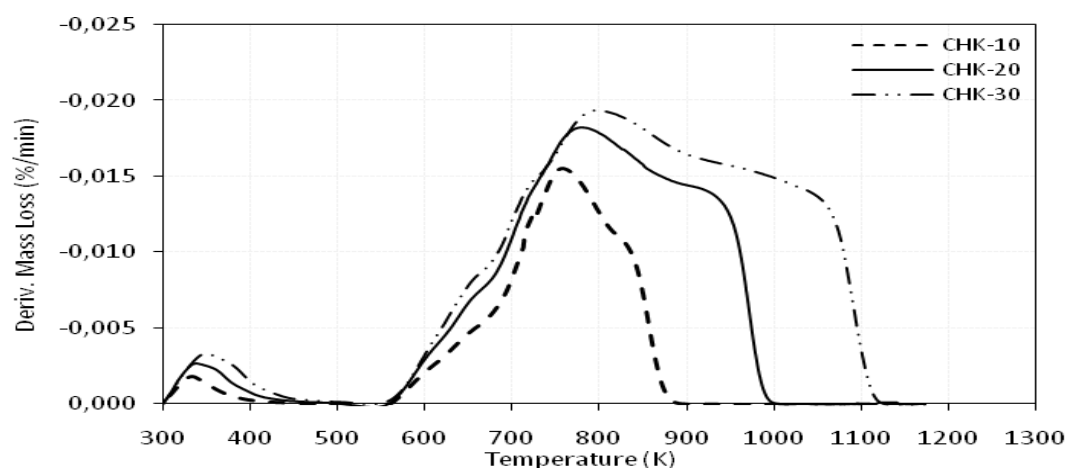

Fig. 2. DTG plots for oxidative thermal analysis of CHK

\subsection{Oxidative Thermal Analysis}

The oxidative thermal analysis of CHK was examined within $298-1173 \mathrm{~K}$ at variable heating rates of 10,20 and $30 \mathrm{~K} / \mathrm{min}$ using the non-isothermal heating program. The resulting thermogravimetric (TG) and derivative thermogravimetric (DTG) curves are presented in Figs. 1 and 2.

The TG curves revealed that the increase in temperature from 298 to $1173 \mathrm{~K}$ results in significant thermal degradation of CHK. The non-isothermal increase in the temperature results in a significant mass loss (91.8- 
$91.9 \%$ ) due to the thermal degradation or breakdown of the complex bonds and chemical components in the coal structure. As a result, CHK undergoes several thermochemical reactions resulting in the release of moisture, condensable and non-condensable gases to yield coke and ash due to the oxidative nature of the process. Similarly, the increase in heating rates from 10 to $30 \mathrm{~K} / \mathrm{min}$ influences the thermal decomposition of CHK. As observed in Fig. 1, the TG plots show a shift to the righthand side based on the higher heating rates. This is attributed to the thermal lag and increased thermal resistance of volatile gases evolved during TGA [25, 29]. These factors reportedly shorten the time required by the sample to attain thermal equilibrium, thereby resulting in a shift or jump in the TG curves to a higher temperature as observed in Fig. 1.

Fig. 2 presents the derivative thermogravimetric (DTG) plots for CHK during oxidative thermal analysis. The DTG plots present the thermal degradation mechanism and reaction paths of thermally degrading materials such as coal [30]. The DTG plots indicated that the change in temperature and heating rates significantly influences the thermal degradation mechanism and reaction pathways of $\mathrm{CHK}$ during the oxidative thermal analysis. As observed, the increase in heating rates from 10 to $30 \mathrm{~K} / \mathrm{min}$ results in the enlargement of the DTG peaks during TGA. This can be ascribed to the higher thermal energy input at higher heating rates, which influence thermal degradation and evolution of condensed and non-condensed gases. As a result, the DTG plots expand in size, although the shape remains intact, indicating that the degradation mechanism is similar. Moreover, the DTG plots are comprised of two sets of endothermic peaks from 298 to $500 \mathrm{~K}$ and from 500 to $900 \mathrm{~K}$ at $10 \mathrm{~K} / \mathrm{min}$, from 500 to $1000 \mathrm{~K}$ at $20 \mathrm{~K} / \mathrm{min}$, and lastly, from 500 to $1153 \mathrm{~K}$ for $30 \mathrm{~K} / \mathrm{min}$. This indicates that the thermal degradation of CHK occurs in two major stages: drying within $298-500 \mathrm{~K}$ and oxidative thermal degradation (combustion) from $500 \mathrm{~K}$ to the final TGA temperatures, as earlier reported.

The first set of peaks below $500 \mathrm{~K}$ can be ascribed to drying due to the low mass loss $(<10 \mathrm{wt} \%)$ that occurs in this temperature range. However, significant mass loss occurs within $500-900,500-1000$ and $500-1153 \mathrm{~K}$ at 10 , 20 and $30 \mathrm{~K} / \mathrm{min}$, respectively. This stage of the process can be ascribed to the loss of coal organic components called macerals at higher temperatures and heating rates. This indicates that increased temperatures and heating rates have a significant effect on the thermal degradation behaviour and temperature profiles during TGA. Section 3.3 examines the effects of reaction conditions on the temperature profile characteristics of $\mathrm{CHK}$ coal.

\subsection{Temperature Profile Characteristics (TPCs)}

The temperature profile characteristics (TPCs) and thermal degradation behaviour of $\mathrm{CHK}$ during the oxidative thermal analysis were examined from the TG and DTG plots in Figs. 1 and 2, respectively. Tables 2 and 3 present the TPCs from the TG and DTG plots, respectively.

The TPCs determined from the TG plots included: ignition $\left(T_{o n}\right)$, midpoint $\left(T_{m i d}\right)$, and burnout $\left(T_{\text {off }}\right)$ temperatures, mass loss rate $(\%)$ and residual mass $\left(R_{M}\right.$, $\%$ ), whereas the drying peak temperature $(\mathrm{K})$ and the devolatilization peak temperature $\left(T_{\max }, \mathrm{K}\right)$ were deduced from the DTG plots. The $T_{\text {on }}$ is the initial temperature at which the sample starts thermally degrading during TGA. The $T_{m i d}$ is the half-way point on the TG plot. The $T_{\max }$ is the maximum decomposition temperature or the temperature at which the highest mass loss rate $(\% / \mathrm{min})$ of the sample occurs. It is typically denoted by a large DTG peak during TGA. The burnout temperature $\left(T_{o f f}\right)$ is the temperature at which the thermal degradation or devolatilization are completed. Lastly, the residual mass $\left(R_{M}, \%\right)$ is the remaining sample mass recorded at the end of TGA. It is a measure of the coke or ash yield of thermally decomposing materials during TGA.

In this study, the $T_{\text {on }}$ decreased from 679.97 to 662.33 with the increase in heating rate, whereas the $T_{\text {mid }}$ increased from 755.35 to $849.34 \mathrm{~K}$, and $T_{\text {off }}$ temperature was from 836.91 to $1010.99 \mathrm{~K}$ with increasing heating rates from 10 to $30 \mathrm{~K} / \mathrm{min}$. The mass loss $\left(M_{L}, \%\right)$ during CHK thermal decomposition initially increased from 91.84 to $91.91 \%$ but then decreased to $91.76 \%$, which resulted in the residual mass change from 8.16 to 8.09 and finally $8.25 \%$. The average values of $T_{o n}, T_{\text {midd }}, T_{\text {off }}, M_{L}$ and $R_{M}$ for CHK are: $669.22 \mathrm{~K}, 802.06 \mathrm{~K}, 929.63 \mathrm{~K}$, $91.84 \%$ and $8.17 \%$, respectively.

Table 2

Temperature profile characteristics (TPCs) of the TG plots

\begin{tabular}{|c|c|c|c|c|c|}
\hline $\begin{array}{c}\text { Heating rate, } \\
\mathrm{K} / \mathrm{min}\end{array}$ & $\begin{array}{c}\text { Ignition temperature, } \\
T_{\text {on }}, \mathrm{K}\end{array}$ & $\begin{array}{c}\text { Midpoint temperature, } \\
T_{\text {mid }}, \mathrm{K}\end{array}$ & $\begin{array}{c}\text { Burnout temperature, } \\
T_{\text {off }}, \mathrm{K}\end{array}$ & $\begin{array}{c}\text { Mass loss, } \\
\%\end{array}$ & $\begin{array}{c}\text { Residual } \\
\text { mass, } \%\end{array}$ \\
\hline 10 & 679.97 & 755.35 & 836.91 & 91.84 & 8.16 \\
\hline 20 & 665.37 & 801.48 & 941.00 & 91.91 & 8.09 \\
\hline 30 & 662.33 & 849.34 & 1010.99 & 91.76 & 8.25 \\
\hline
\end{tabular}


Temperature profile characteristics (TPCs) of the DTG plots

\begin{tabular}{|c|c|c|}
\hline Heating rate, $\mathrm{K} / \mathrm{min}$ & Drying peak temperature, $\mathrm{K}$ & Devolatilization peak temperature, $\mathrm{K}$ \\
\hline 10 & 333.80 & 758.37 \\
\hline 20 & 338.85 & 780.62 \\
\hline 30 & 348.20 & 796.65 \\
\hline
\end{tabular}

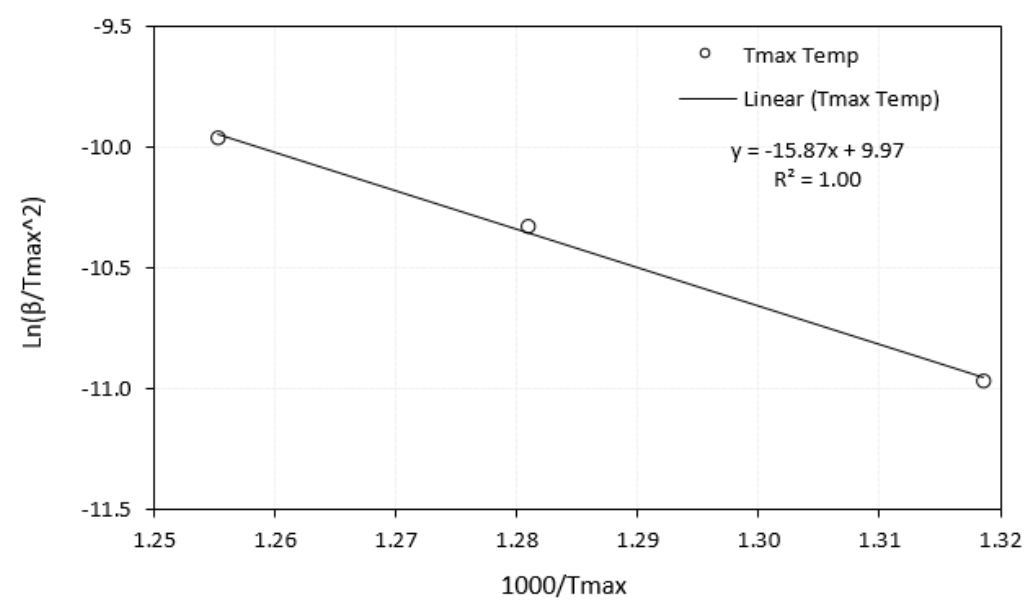

Fig. 1. Kissinger kinetic plots for combustion of CHK coal

Further analysis revealed that the increase in heating rates from 10 to $30 \mathrm{~K} / \mathrm{min}$ increased the $T_{\text {mid }}, T_{\text {off }}$ and $R_{M}$ values to higher ones. However, the increase in heating rates lowered the values of $T_{o n}$ and $M_{L}$ during TGA. This indicates that higher heating rates enhanced the ignition $\left(T_{o n}\right)$ and thermal degradation $\left(M_{L}\right)$ due to higher thermal input during TGA. As a result, the onset of thermal degradation of $\mathrm{CHK}$ occurred earlier at higher heating rates, thereby increasing the overall time of degradation and the mass loss.

The effect of heating rates on TPCs was also examined as presented in Table 3. As observed in Fig. 2, the mass loss occurred in two stages: drying and the degradation of volatile matter in the coal structure, which are characterised by peak values denoted as the drying peak and devolatilization peak temperatures.

As observed in Table 3, the increase in heating rates from 10 to $30 \mathrm{~K} / \mathrm{min}$ increases the maximum drying peak and devolatilization peaks temperatures during TGA. The drying peaks increased from 333.80 to $348.20 \mathrm{~K}$, whereas the devolatilization peaks increased from 758.37 to $796.65 \mathrm{~K}$. On average, the values for the maximum drying and devolatilization peaks are 340.28 and $778.55 \mathrm{~K}$, respectively.

\subsection{Combustion Kinetic Analysis}

The kinetic analysis of CHK coal during oxidative thermal analysis was examined through the Kissinger kinetic model as described in Eq. (1). The values of $T_{\max }$ presented in Table 3 were substituted into Eq. (1) to determine the plot of $\ln \left(\beta / T^{2}{ }_{m}\right)$ vs. $1000 / T_{m}$ for the decomposition of $\mathrm{CHK}$ at different heating rates $\beta$ (10$30 \mathrm{~K} / \mathrm{min}$ ). Based on the slope and intercepts of the kinetic plot and the equation of the line in Fig. 3, the activation energy $\left(E_{a}, \mathrm{~kJ} / \mathrm{mol}\right)$ and frequency $\left(A, \min ^{-1}\right)$ were calculated through the Kissinger model.

The kinetic parameters for the oxidative thermal analysis (combustion) of CHK are: $E_{a}=131.92 \mathrm{~kJ} / \mathrm{mol}$, and $A=3.4 \cdot 10^{5} \mathrm{~min}^{-1}$. In comparison, the oxidative kinetic parameters reported for CHK reported by Sonibare et al. [21] are: $E_{a}=82.6 \mathrm{~kJ} / \mathrm{mol}$ and $A=5.8 \cdot 10^{1} \mathrm{~min}^{-1}$. As can be observed, the kinetic parameters differ markedly from the values reported in this paper. The difference is due to the difference in kinetic methods (model fitting approach of Coats-Redfern) used by the authors as opposed to the "model-free" Kissinger kinetic methods used in this paper.

\section{Conclusions}

The study examined the combustion characteristics and oxidative thermal kinetics of Chikila coal (CHK) from the upper Benue trough in Nigeria. In addition, the physico-chemical, calorific, and temperature profile fuel properties were examined. The results revealed that $\mathrm{CHK}$ contains high $\mathrm{C}, \mathrm{H}, \mathrm{O}, \mathrm{FC}$ and $\mathrm{VM}$ but low N, S, MC and $\mathrm{AC}$ contents. The high concentration of combustible elements also accounts for the high calorific value $(\mathrm{HHV}=30.70 \mathrm{MJ} / \mathrm{kg})$ of $\mathrm{CHK}$. The results also 
demonstrated that CHK can undergo thermal degradation ( $M_{L}=91.8 \%, R_{M}=8.2 \%$ on average), when subjected to the temperatures of $298-1173 \mathrm{~K}$ and heating rates of 10 $30 \mathrm{~K} / \mathrm{min}$ under non-isothermal oxidative conditions. In addition, the plots for TG and DTG along with the TPCs were significantly influenced by the variation in temperatures and heating rates. Lastly, the kinetic analysis revealed that the kinetic parameters for CHK degradation are: $E_{a}=131.92 \mathrm{~kJ} / \mathrm{mol}$ and $A=3.4 \cdot 10^{5} \mathrm{~min}^{-1}$. The $E_{a}$ and $A$ values were calculated from the "model-free" Kissinger kinetic methods. Based on the results of the study, CHK is a potentially good feedstock with a high composition of fuel elements, heating value, along with low ash and pollutant precursors for future energy recovery or industrial utilization.

\section{Acknowledgements}

The material and technical support of National Metallurgical Research and Development Centre (NMRDC, Plateau State Nigeria), National Centre for Petroleum Research \& Development (NCPRD-ATBU, Bauchi State, Nigeria) and Hydrogen \& Fuel Cell Laboratory (UTM, Malaysia) are gratefully acknowledged.

\section{References}

[1] IEA, Market Series Report: IEA Coal 2017, Paris, France, 1-8.

[2] Speight J.: The Chemistry and Technology of Coal. CRC Press, Boca Raton 2012, https://doi.org/10.1201/b12497

[3] IEA-WEO 2013. http://bit.ly/1davgFh

[4] OECD Working Paper, 2012.

http:/www.oecd.org/chile/publicationsdocuments/workingpapers/

[5] Nyakuma BB., Jauro A., Oladokun O. et al.: Petrol. Coal, 2018, 60, 641 .

[6] Nyakuma BB., Oladokun O., Jauro A. et al.: IOP Conf. Ser. Mat. Sci. Eng., 2017, 217, 012013. https://doi.org/10.1088/1757$899 \mathrm{X} / 217 / 1 / 012013$

[7] Iwayemi A.: Int. Assoc. Energ Econ., 2008, 53, 17.

[8] Oyedepo S.: Renew. Sust. Energ. Rev., 2012, 16, 2583.

https://doi.org/10.1016/j.rser.2012.02.010

[9] Emodi N.: Energy Policies for Sustainable Development

Strategies. Springer, Singapore 2016, 9-67.

[10] Ohimain E.: Int. J. Energ. Power Eng., 2014, 3, 28.

https://doi.org/10.11648/j.ijepe.20140301.15

[11] Chukwu M., Folayan C., Pam G. et al.: J. Comb., 2016, 2016. https://doi.org/10.1155/2016/9728278

[12] Sambo A., Garba B., Zarma I., Gaji M.: J. Energ. Power Eng. 2012, 6, 1050. https://doi.org/10.17265/1934-8975/2012.07.005

[13] Nyakuma BB., Oladokun O., Jauro A. et al.: IOP Conf. Ser. Mat. Sci. Eng., 2017, 217, 012012. https://doi.org/10.1088/1757$899 \mathrm{X} / 217 / 1 / 012012$
[14] Jauro A., Obaje N., Agho M. et al.: Fuel, 2007, 86, 520. https://doi.org/10.1016/j.fuel.2006.07.031

[15] Sonibare O., Jacob D., Foley S.: Energ. Source. Part A, 2013, 35, 753. https://doi.org/10.1080/15567036.2010.514781

[16] Ayinla H., Abdullah W., Makeen Y. et al.: Int. J. Coal Geol., 2017, 173, 212. https://doi.org/10.1016/j.coal.2017.02.011

[17] Ryemshak S., Jauro A.: Int. J. Ind. Chem., 2013, 4, 7. https://doi.org/10.1186/2228-5547-4-7

[18] Nasirudeen M., Jauro A.: J. Minerals Mat. Charact. Eng., 2011, 10, 101. https://doi.org/10.4236/jmmce.2011.101007

[19] Odeh A.: Energy, 2015, 87, 555.

https://doi.org/10.1016/j.energy.2015.05.019

[20] Ayinla H., Abdullah W., Makeen Y. et al.: Int. J. Coal Geol., 2017, 180, 67. https://doi.org/10.1016/j.coal.2017.06.010

[21] Sonibare O., Ehinola O., Egashira R. et al.: J. Appl. Sci., 2005, 5, 104. https://doi.org/10.3923/jas.2005.104.107

[22] Nkafamiya I., Makan S., Akinterinwa A. et al.: Am. J. Chem., 2017, 7, 67-72. https://doi.org/10.5923/j.chemistry.20170703.01

[23] Jauro A., Chigozie A., Nasirudeen M.: Sci. World J., 2008, 3. https://doi.org/10.4314/swj.v3i2.51799

[24] Donahue C., Rais E.: J. Chem. Educ., 2009, 86, 222. https://doi.org/10.1021/ed086p222

[25] Slopiecka K., Bartocci P., Fantozzi F.: Appl. Energ., 2012, 97, 491. https://doi.org/10.1016/j.apenergy.2011.12.056

[26] Vassilev S., Vassileva C., Vassilev V.: Fuel, 2015, 158, 330. https://doi.org/10.1016/j.fuel.2015.05.050

[27] ASTM D388-12.

https://www.astm.org/DATABASE.CART/HISTORICAL/D38812.htm

[28] Sonibare O., Haeger T., Foley S.: Energy, 2010, 35, 5347. https://doi.org/10.1016/j.energy.2010.07.025

[29] Damartzis T., Vamvuka D., Sfakiotakis S. et al.: Biores. Tech., 2011, 102, 6230. https://doi.org/10.1016/j.biortech.2011.02.060 [30] Nyakuma BB., Jauro A., Oladokun O. et al.: J. Phys. Sci., 2016, 27, 1. https://doi.org/10.1515/gse-2016-0017

Received: November 23, 2018 / Revised: January 03, 2018 / Accepted: April 16, 2019

\section{ВИЗНАЧЕННЯ ХАРАКТЕРИСТИК ГОРІННЯ ВУГІЛЛЯ ЧИКІЛА 3 ВИКОРИСТАННЯМ МОДЕЛІ КІССІНДЖЕРА}

\begin{abstract}
Анотація. Досліджено характеристики згоряння вугілля Чикіла (СНК) з Нігерії. Встановлено, щчо СНК має високий вміст карбону та нелеткого карбону, але низький вміст нітрогену, сульфуру та золи. На основі встановленої величини теплотворної здатності вугілля, воно класифіковано як високолетуче бітумінозне вугілля марки В. За допомогою термогравіметричного аналізу визначено температурні характеристики вугілля. На основі моделі Кіссінджера досліджено кінетику згоряння СНК. Показано, що СНК є потенційною сировиною для майбутньої рекуперачії енергії та промислової утилізаиіi.
\end{abstract}

Ключові слова: спалювання, термокінетика, вугілля Чикіла. 